\title{
The total synthesis of (-)-cyanthiwigin $\mathrm{F}$ by means of double catalytic enantioselective alkylation
}

\author{
John A. Enquist $\mathbf{J r}^{1}$ and Brian M. Stoltz ${ }^{1}$ \\ 1 The Arnold and Mabel Beckman Laboratories of Chemical Synthesis, Division of Chemistry and Chemical \\ Engineering, California Institute of Technology, 1200 East California Boulevard, MC164-30, Pasadena, \\ California 91125, USA.
}

\begin{abstract}
Double catalytic enantioselective transformations are powerful synthetic methods that can facilitate the construction of stereochemically complex molecules in a single operation ${ }^{1,2}$. In addition to generating two or more stereocentres in a single reaction, multiple asymmetric reactions also impart increased enantiomeric excess to the final product in comparison with the analogous single transformation $^{3-6}$. Furthermore, multiple asymmetric operations have the potential to independently construct several stereocentres at remote points within the same molecular scaffold, rather than relying on pre-existing chiral centres that are proximal to the reactive site ${ }^{1}$. Despite the inherent benefits of multiple catalytic enantioselective reactions, their application to natural product total synthesis remains largely underutilized ${ }^{2}$. Here we report the use of a double stereoablative ${ }^{7}$ enantioselective alkylation reaction in a concise synthesis of the marine diterpenoid (-)-cyanthiwigin $\mathrm{F}$ (ref. 8). By employing a technique for independent, selective formation of two stereocentres in a single stereoconvergent operation, we demonstrate that a complicated mixture of racemic and meso diastereomers may be smoothly converted to a synthetically useful intermediate with exceptional enantiomeric excess. The stereochemical information generated by means of this catalytic transformation facilitates the easy and rapid completion of the total synthesis of this marine natural product.
\end{abstract}

Originally isolated from the sea sponge Myrmekioderma styx, cyanthiwigin F (1; see Fig. 1) is one of 30 known cyanthiwigin natural products, all of which belong to a larger class of bioactive molecules known as the cyathins $8-10$. The cyathins display a wide range of biological properties including antimicrobial activity, antineoplastic action, stimulation of nerve growth factor synthesis, and $\kappa$-opioid receptor agonism ${ }^{9,11}$. Cyanthiwigin $\mathrm{F}$ itself exhibits cytotoxic activity against human primary tumour cells (with a half-maximal inhibitory concentration of $\left.3.1 \mathrm{~kg} \mathrm{~mL}^{-1}\right)^{8}$. A skeletal representation of the cyathins (that is, 2; see Fig. 1) depicts the 20carbon tricyclic core bearing two all-carbon quaternary stereocentres at the $\mathrm{A}-\mathrm{B}$ and $\mathrm{B}-\mathrm{C}$ ring junctures. Synthetic control of the relative and absolute stereochemistries of these quaternary centres along with the construction of the tricyclic framework of the cyathins represent significant challenges to their laboratory preparation ${ }^{12,13}$. Despite their structural and biological significance, only two of the 30 cyanthiwigin molecules isolated so far have been accessed by total synthesis ${ }^{14,15}$. Owing to the promising activity and low natural abundance of these molecules, total synthesis remains an important technique in the production of these compounds in quantities sufficient for further study. Moreover, a succinct and general approach

Correspondence and requests for materials should be addressed to B.M.S. (stoltz@ caltech.edu).

Author Information Crystallographic data have been deposited at the Cambridge Crystallographic Data Centre, 12 Union Road, Cambridge CB2 1EZ, UK, and copies can be obtained on request, free of charge, by quoting the publication citation and the deposition number 664430. Reprints and permissions information is available at www.nature.com/reprints. 
to such a synthetic effort may provide a strategic opportunity for the preparation of many other members of the cyanthiwigin family.

Our retrosynthetic approach to cyanthiwigin $\mathrm{F}$ focused on initial construction of the central B ring, with the intention of rapidly establishing both of the all-carbon quaternary stereocentres present at the ring junctures of the natural product (Fig. 1). To this end, we envisioned latestage construction of the five-member A ring, leading back to bicyclic ketone 3 . We anticipated that this bicyclic structure would be accessible by means of ring-closing metathesis of cyclohex-anone 4, which itself could be prepared via Negishi cross-coupling of vinyl triflate 5. Critically, we envisioned that triflate $\mathbf{5}$ could be obtained from monoanionic desymmetrization of cyclohexanedione $\mathbf{6}$ (ref. 16). We recently developed a powerful methodology for the construction of all-carbon quaternary stereocentres using a chiral palladium catalyst to mediate the asymmetric alkylation of in situ-generated cyclic ketone enolates 17,18 . Using this technology, we anticipated that cyclohexanedione 6 could be accessed through enantioselective allylation of bis( $\beta$-ketoester) 7 , which could be generated from diallyl succinate (8; see Fig. 2a). Indeed, in a model substrate, a double asymmetric alkylation using our protocol proved successful ${ }^{18}$.

A key challenge presented by the current system is that it represents the first Pd-catalysed double stereoablative alkylation event involving two different ketones contained within a single ring to generate two all-carbon quaternary stereocentres. Additionally, the current substrate is unique in that a mixture of diastereomers and enantiomers would be converted to a single stereoisomer of product. This transformation would be particularly noteworthy because nonselective catalytic ablation of two quaternary centres in the substrate would precede highly enantio- and diastereoselective construction of two central quaternary centres. Vital to our overall synthetic plan was that it required no functionality-masking by means of protecting or caging groups 19 . Such syntheses are strategically streamlined owing to the lack of protection and deprotection steps, operations that inherently add two chemical manipulations per protecting group to any synthetic plan. Although notable examples of protecting group-free total syntheses exist ${ }^{20-23}$, they are difficult to accomplish and remain relatively uncommon, particularly in the catalytic enantioselective total synthesis of complex molecules.

The preparation of the key diketone was initiated by the self-condensation of diallyl succinate 8 using a Claisen-Dieckmann process, which was followed by methylation using potassium carbonate and methyl iodide to form bis( $\beta$-ketoester) 7 in $51 \%$ yield over two steps (Fig. 2a) 24 . This reaction affords 7 as a $1: 1$ mixture of racemic $((S, S)-7$ plus $(R, R)-7)$ and meso diastereomers, and can be performed conveniently in 60-g batches of 8 . (Routine synthetic experimental techniques were used for the preparation, isolation, and analysis of all new compounds and are described in the Supplementary Information.) Having obtained bis( $\beta$ ketoester) 7, we were prepared to expose it to the conditions of our Pd-catalysed enantioselective allylation. Typically, use of such a stereoisomeric mixture in an asymmetric transformation would be deleterious to a total synthesis, because the presence of two preexisting stereocentres in the substrate could interfere with inherent catalyst selectivity and afford reduced quantities of the desired product ${ }^{25}$. The potential for developing mismatched catalyst-substrate interactions that negatively impact yield and selectivity was a major concern, as was the possibility of a kinetic resolution 26 .

The number of possible stereochemical outcomes and the number of pathways leading to each potential product renders the situation quite complex (Fig. 2b). Beginning from the diastereomeric mixture of 7, the substrate must initially undergo decarboxylative deallylation to produce racemic enolate $\mathbf{9}$, which is subsequently monoalkylated to form ester $\mathbf{1 0}$. If the enantiopure catalyst controls formation of the new stereocentre ${ }^{17,18}$, a mixture of ester diastereomers 10 will arise, with $(R, R)-\mathbf{1 0}$ and $(R, S)$-10 each predominating over both $(S$, 
$R)-\mathbf{1 0}$ and $(S, S)$-10. Influence of the remaining substrate stereocentre may either reinforce or conflict with catalyst control during this process. From these intermediate monoesters, a second stereoablative process would then generate a non-racemic mixture of enolates $(R)-\mathbf{1 1}$ and $(S)$-11. Last, a second facially selective alkylation affords the double alkylation products as a diastereomeric mixture of enantioenriched $(R, R)-\mathbf{6}$ and meso-6. For the reaction to proceed favourably a number of criteria must be met: the catalyst must not stereoselectively influence the stereoablative steps appreciably; the catalyst must impose a high degree of facial selectivity at all stages of bond construction; and the diastereoselective bias for alkylation inherent in the substrate must not override the influence of the catalyst. If these requirements are met, it is expected that the major product of the reaction will benefit from a statistical amplification of its enantiomeric excess, in line with theories first described in ref. ${ }^{3}$ and later detailed both experimentally and computationally in refs $4-6$.

In practice, treatment of a 1:1 mixture of diastereomers (or either pure diastereomer) of bis( $\beta$ ketoester) 7 with $\mathrm{Pd}(\mathrm{dmdba})_{2}(5 \mathrm{~mol}$ per cent) and enantiopure tert-butyl phosphinooxazoline (PHOX) ligand 2712 (5.5 mol per cent) in $\mathrm{Et}_{2} \mathrm{O}$ at $25^{\circ} \mathrm{C}$ affords the bisalkylated products enantioenriched $\mathbf{6}$ and meso- $\mathbf{6}$ as a 4.4:1 mixture in 78\% yield. Moreover, we found that the major diastereomer of $\mathbf{6}$ is formed in $99 \%$ enantiomeric excess. In this single-step procedure, two all-carbon quaternary stereocentres were simultaneously constructed with excellent enantioselectivity, thus addressing what is arguably the greatest synthetic challenge to the preparation of cyanthiwigin F. It is important to note that although this reaction may progress through any of sixteen different pathways to afford any of three different stereoisomers, the high degree of stereoconvergence and stereochemical control imparted by the catalyst system predominantly favours formation of the desired diketone $(R, R)-\mathbf{6}$.

The completion of the synthesis of cyanthiwigin $\mathrm{F}$ (1) proceeds rapidly owing to the high level of stereochemical value and functionality present in cyclohexanedione 6. Selective monoenolization of diketone $\mathbf{6}$ with potassium bis(trimethylsilyl)amide (KHMDS) and trapping of the resulting potassium enolate as a trifluoromethane-sulfonate is followed by a Pd-catalysed Negishi cross-coupling to introduce an olefinic side chain and generate tetraene 4 (Fig. 3a) ${ }^{28}$. To advance this material, we required closure of the seven-member ring, as well as elaboration of the terminal allyl group to a functional moiety appropriate for completion of the tricyclic cyathin core. We found that both transformations could be effected with a single catalytic operation by treating 4 with Grubbs' ruthenium catalyst 13 (ref. 29) and a vinyl boronate species (14). This provided an efficient and mild method to simultaneously execute both ring-closing metathesis to form the $\mathrm{C}$ ring and cross-metathesis with vinyl boronate $\mathbf{1 4}$ to elaborate the terminal olefin. Upon oxidative work-up, bicyclic aldehyde $\mathbf{1 5}$ was isolated in a single step.

Completion of the carbocyclic core of cyanthiwigin $\mathrm{F}$ was then achieved through radicalinduced intramolecular cyclization of the aldehyde moiety in bicyclic compound $\mathbf{1 5}$ onto the trisubstituted olefin of the central B ring. This was accomplished by treatment of $\mathbf{1 5}$ with $t$ $\mathrm{BuSH}$ and azobis(isobutylnitrile) (AIBN) at $80^{\circ} \mathrm{C}$ to produce tricyclic diketone $\mathbf{1 6}$ as a single diastereomer ${ }^{30}$. We found that this reaction afforded only the desired cis-fused A-B ring juncture with an accompanying trans relationship across the $\mathrm{B}-\mathrm{C}$ ring fusion. We postulate that these configurations result from the kinetic formation of the $\mathrm{C} 3-\mathrm{C} 4$ bond, followed by subsequent kinetic hydrogen atom abstraction at $\mathrm{C} 5$ to establish the more thermodynamically stable ring fusion. Recrystallization of this material from acetonitrile and water allowed for unambiguous assignment of the relative stereochemistry by X-ray crystallography (Fig. 3b). Once we had tricyclic compound 16, selective enol triflate formation was followed by a difficult Pd-catalysed coupling reaction with an $i$-Pr-organocuprate reagent to afford cyanthiwigin $\mathrm{F}$ (1) and a reduction product (that is, 17) as a 1.8:1 mixture in 63\% combined yield. Isolation 
of the major component of this mixture affords cyanthiwigin $\mathrm{F}$ in only nine steps from diallyl succinate.

In conclusion, we have achieved the catalytic enantioselective synthesis of the cyathin diterpenoid (-)-cyanthiwigin F. Our synthetic route features an enantioselective Pd-catalysed double alkylation reaction as the pivotal step by which stereochemistry is established about the central B ring of the molecule. Use of this stereoconvergent approach allowed us to employ classic scaleable condensation chemistry in the early stages of our route (that is, ClaisenDieckmann cyclization), and provided the critical stereochemical information necessary to guide the final steps of our synthesis. From this point, an efficient tandem ring-closing metathesis/cross-metathesis reaction followed by a thiol-mediated radical cyclization allowed for rapid elaboration to the natural product, without the use of protecting groups. This short synthetic route highlights the utility of double enantioselective transformations in the construction of molecules with high levels of stereochemical complexity, and uses low catalyst loading, is not very difficult operationally, and results in exceptional enantioselectivity. We hope that the results reported here will encourage greater investigation into multiple catalytic enantioselective processes. Implementation of this strategy for the synthesis of other cyanthiwigin natural products and studies towards the use of double enantioselective reactions in the easy preparation of various complex molecules are ongoing.

\section{Supplementary Material}

Refer to Web version on PubMed Central for supplementary material.

\section{Acknowledgements}

The authors wish to thank NIH-NIGMS (R01GM080269-01), Amgen, Abbott, Boehringer Ingelheim, Merck and Bristol-Myers Squibb for financial support. We also wish to thank M. W. Day and L. M. Henling for X-ray crystallographic expertise, S. Virgil, A. Harned, D. White, D. Caspi and J. T. Mohr for helpful discussions, and M. T. Hamann for an authentic sample and spectra of cyanthiwigin F. We thank E. J. Corey for guidance and mentorship, on the occasion of his 80th birthday.

\section{References}

1. Masamune S, Choy W, Petersen J, Sita L. Double asymmetric synthesis and a new strategy for stereocontrol in organic synthesis. Angew Chem Int Edn Engl 1985;24:1-30.

2. Kolodiazhnyi OI. Multiple stereoselectivity and its applications in organic synthesis. Tetrahedron 2003;59:5953-6018.

3. Langenbeck W, Triem G. Zur Theorie der Erhaltung und Entstehung optischer Aktivität in der Natur. Z Phys Chem A 1936;117:401-409.

4. Vigneron JP, Dhaenens M, Horeau A. Nouvelle méthode pour porter au maximum la pureté optique d'un produit partiellement dédoublé sans l'aide d'aucune substance chirale. Tetrahedron 1973;29:1055-1059.

5. Rautenstrauch V. The two expressions of the Horeau principle, nth-order Horeau amplifications, and scales for the resulting very high enantiopurities. Bull Soc Chim Fr 1994;131:515-524.

6. Baba SE, Sartor K, Poulin J, Kagan H. Tandem asymmetric syntheses from achiral precursors asymmetric homogeneous reduction of bisdehydrodipeptides. Bull Soc Chim Fr 1994;131:525-533.

7. Mohr JT, Ebner DC, Stoltz BM. Catalytic enantioselective stereoablative reactions: an unexploited approach to enantioselective catalysis. Org Biomol Chem 2007;5:3571-3576. [PubMed: 17971984]

8. Peng J, et al. The new bioactive diterpenes cyanthiwigin E-AA from the Jamaican sponge Myrmekioderma styx. Tetrahedron 2002;58:7809-7819.

9. Sennett SH, Pomponi SA, Wright AE. Diterpene metabolites from two chemo-types of the marine sponge Myrmekioderma styx. J Nat Prod 1992;55:1421-1429. [PubMed: 1453179]

10. Peng J, Avery MA, Hamann MT. Cyanthiwigin AC and AD, two novel diterpene skeletons from the Jamaican sponge Myrmekioderma styx. Org Lett 2003;5:4575-4578. [PubMed: 14627387] 
11. Saito T, et al. Erinacine E as a kappa opioid receptor agonist and its new analogs from a basidiomycete, Hericium ramosum. J Antibiot (Tokyo) 1998;51:983-990. [PubMed: 9918390]

12. Cozzi PG, Hlgraf R, Zimmermann N. Enantioselective catalytic formation of quaternary stereogenic centers. Eur J Org Chem 2007;2007:5969-5994.

13. Trost BM, Jiang C. Catalytic enantioselective construction of all-carbon quaternary stereocenters. Synthesis 2006:369-396.

14. Pfeiffer MWB, Phillips AJ. Total synthesis of (+)-cyanthiwigin U. J Am Chem Soc 2005; 127:53345335. [PubMed: 15826167]

15. Reddy JT, Bordeau G, Trimble L. Total synthesis of (+)-cyanthiwigin AC. Org Lett 2006;8:55855588. [PubMed: 17107078]

16. Poss CS, Schreiber SL. Two-directional chain synthesis and terminus differentiation. Acc Chem Res 1994;27:9-17.

17. Behenna DC, Stoltz BM. The enantioselective Tsuji allylation. J Am Chem Soc 2004;126:1504415045. [PubMed: 15547998]

18. Mohr JT, Behenna DC, Harned AM, Stoltz BM. Deracemization of quaternary stereocenters by Pdcatalyzed enantioconvergent decarboxylative allylation of racemic $\beta$-ketoesters. Angew Chem Int Edn Engl 2005;44:6924-6927.

19. Greene, T.; Wuts, P. Protective Groups in Organic Synthesis. Wiley; New York: 1999.

20. Robinson R. A synthesis of tropinone. J Chem Soc 1917;111:762-768.

21. Hoffmann RW. Protecting-group-free synthesis. Synthesis 2006:3531-3541.

22. McFadden RM, Stoltz BM. The catalytic enantioselective, protecting group-free total synthesis of (+)-dichroanone. J Am Chem Soc 2006;128:7738-7739. [PubMed: 16771478]

23. Baran PS, Maimone TJ, Richter JM. Total synthesis of marine natural products without using protecting groups. Nature 2007;446:404-408. [PubMed: 17377577]

24. Ebert H. Zur Constitution des Succinylobernsteinsäureäthers. Liebigs Ann Chem 1885;229:45-88.

25. Kagan H. Various aspects of the reaction of a chiral catalyst or reagent with a racemic or enantiopure substrate. Tetrahedron 2001;57:2449-2468.

26. Eliel, EL.; Wilen, SH. Stereochemistry of Organic Compounds. Wiley; New York: 1994. p. 965-971.

27. Helmchen G, Pfaltz A. Phosphinooxazolines-a new class of versatile, modular P,N-ligands for asymmetric catalysis. Acc Chem Res 2000;33:336-345. [PubMed: 10891051]

28. Taishi T, Takechi S, Mori S. First total synthesis of ( \pm )-stachyflin. Tetrahedr Lett 1998;39:43474350.

29. Stewart IC, et al. Highly efficient ruthenium catalysts for the formation of tetrasubstituted olefins via ring-closing metathesis. Org Lett 2007;9:1589-1592. [PubMed: 17378575]

30. Yoshikai K, Hayama T, Nishimura K, Yamada K, Tomioka K. Thiol-catalyzed acyl radical cyclization of alkenals. J Org Chem 2005;70:681-683. [PubMed: 15651818] 


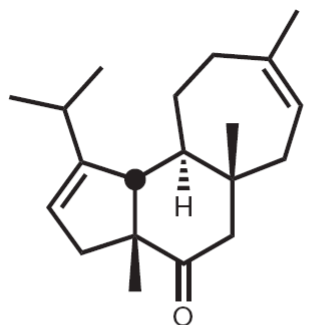

Cyanthiwigin $\mathrm{F}$ (1)

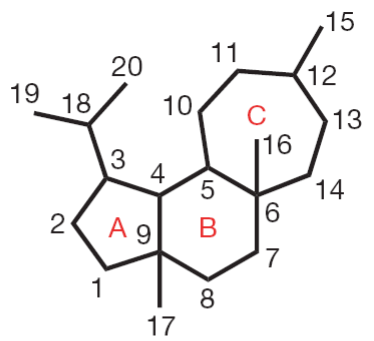

Cyathin carbocyclic core (2)<smiles>C=CC[C@]1(C)C=C2CCC(C)=CC[C@]2(C)CC1=O</smiles><smiles>[R]C1=C[C@](C)(CC=C)C(=O)C[C@]1(C)CC=C</smiles>

3

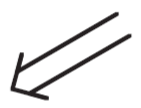<smiles>C=CC[C@@]1(C)CC(=O)[C@](C)(CC=C)CC1=O</smiles><smiles>[Z9]P=[13CH][14CH2][14CH2]CC(=C)C</smiles>

5, $\mathrm{R}=\mathrm{OSO}_{2} \mathrm{CF}_{3}$

Figure 1.

Structure and retrosynthesis of cyanthiwigin F. 
a

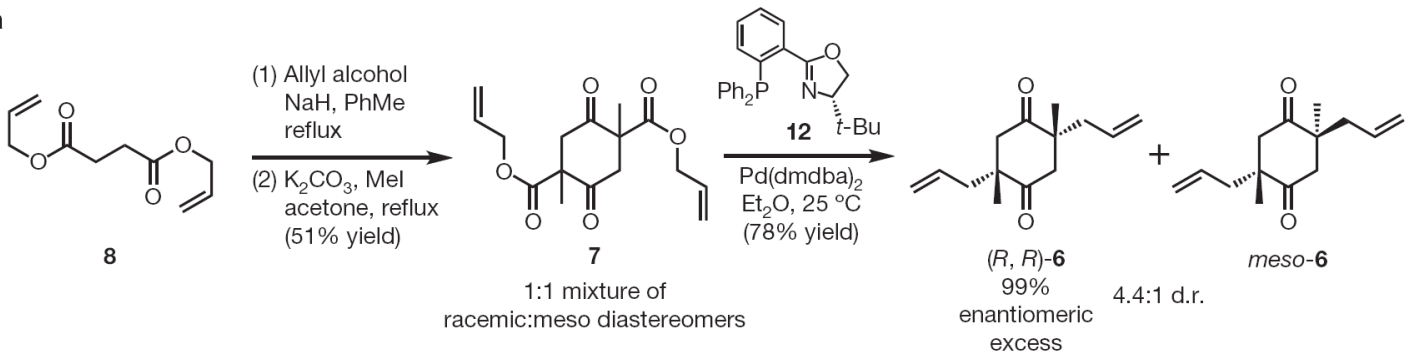

b<smiles>C=CCOC(=O)[C@H]1CC(=O)[C@@](C(=O)OCC)(C(=O)OCCCOC)CC1=O</smiles>

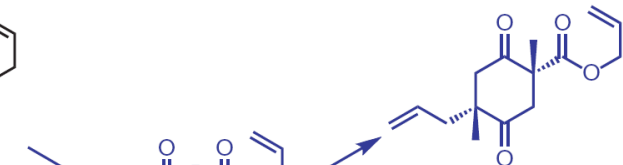

$(R, R)-7$<smiles>C=CCOC(=O)[C@@]1(C)CC(=O)CC(C)=C1O</smiles><smiles>C=CCOC(=O)[C@@H]1CC(=O)C(C(=O)OCC=C)(C(=O)OCC=C)CC1=O</smiles>

(R) -9<smiles>C=CCOC(=O)[C@@H]1CC(=O)[C@H](CC=C)CC(=O)[C@H]1C(=O)OCC</smiles><smiles>C=CC[C@H]1CC(=O)[C@H](C)[C@H](CC=CCCCCCCC)CC1=C</smiles>

meso- $(R, S)-7$<smiles>C=CCOC(=O)[C@H]1CC(=O)[C@H](C(=O)OCC)CC(=O)[C@@H]1C(=O)OCCC</smiles>

(S, S)-7
$(R, R)-6$

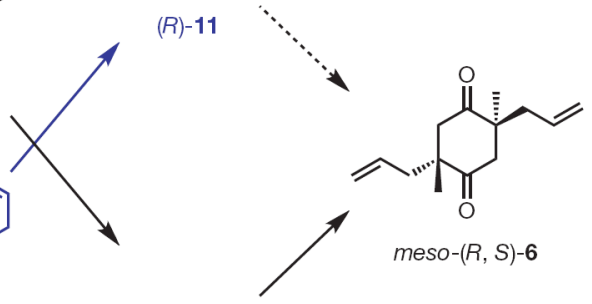

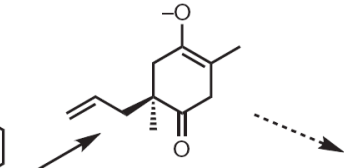

(S)-11

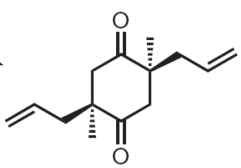

$(S, S)-6$

$(S, S)-10$

Figure 2. Synthesis of diketone 6

a, Implementation of the double asymmetric alkylation. $8 \rightarrow 7:$ (1) $\mathrm{NaH}$ (2.5 equiv.), allyl alcohol (0.28 equiv.), diallyl succinate (8, 1.0 equiv.), $\mathrm{PhMe}$ (toluene), $95^{\circ} \mathrm{C}, 2 \mathrm{~h}$; (2) $\mathrm{K}_{2} \mathrm{CO}_{3}$ (4.1 equiv.), diallyl succinylsuccinate (1.0 equiv.), MeI (5.1 equiv.), acetone, $50{ }^{\circ} \mathrm{C}, 6$ h, $51 \%$ yield over two steps. $7 \rightarrow \mathbf{6 :} \mathrm{Pd}(\mathrm{dmdba})_{2}$ ( 0.05 equiv. $), S$ - $t$-BuPHOX (12, 0.055 equiv.), $\mathrm{Et}_{2} \mathrm{O}, 25^{\circ} \mathrm{C}$, precomplexation for $30 \mathrm{~min}$, then bis( $\beta$-ketoester) 7 (1.0 equiv.), $25^{\circ} \mathrm{C}$ for an additional 10 h, $78 \%$ yield, 4.4:1 diastereomeric ratio (d.r.), $99 \%$ enantiomeric excess. b, Stereochemical analysis for the stereoconvergent double decarboxylative alkylation of $\mathbf{7}$. dmdba, bis(3,5-dimethoxybenzylidene)acetone; $t$-BuPHOX, $t$-butyl phosphinooxazoline. For tabulated spectral data of all depicted compounds, please see the Supplementary Information. 
a

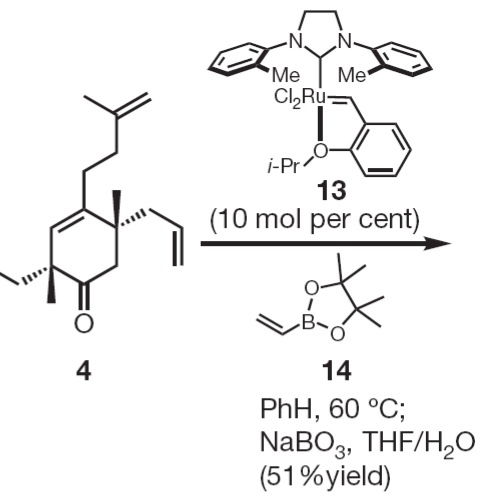

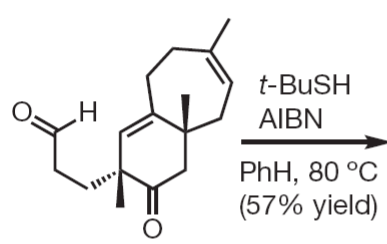

15
(1) KHMDS

$\mathrm{PhN}(\mathrm{Tf})_{2}$<smiles>C=CC[C@]1(C)CC(=O)C[C@](C)(C=C)C1=O</smiles>

THF, $-78^{\circ} \mathrm{C}$

$(73 \%$ yield $)$

(2) Zn, TMSCl

1,2-dibromoethane

1,

THF, $65^{\circ} \mathrm{C}$

then $\mathrm{Pd}\left(\mathrm{PPh}_{3}\right)_{4}$

(78\% yield)

(51\%yield)

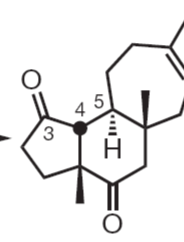

16
(1) $\mathrm{KHMDS}$
$\mathrm{PhN}(\mathrm{Tf})_{2}$
$\mathrm{THF},-78^{\circ} \mathrm{C}$
$\underset{(60 \% \text { yield })}{\longrightarrow}$
$\underset{(2)}{ } \mathrm{i}-\mathrm{PrMgCl}$
$\mathrm{CuCN}, \mathrm{THF} ;$
$\mathrm{Pd}(\mathrm{dppf}) \mathrm{Cl}_{2}$ (63\% yield) (1.8:1 mixture of 1:17)

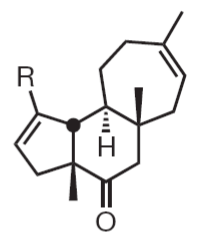

1, $\mathrm{R}=i-\mathrm{Pr}$,

$(-)$-cyanthiwigin $\mathrm{F}$ 17, $\mathrm{R}=\mathrm{H}$

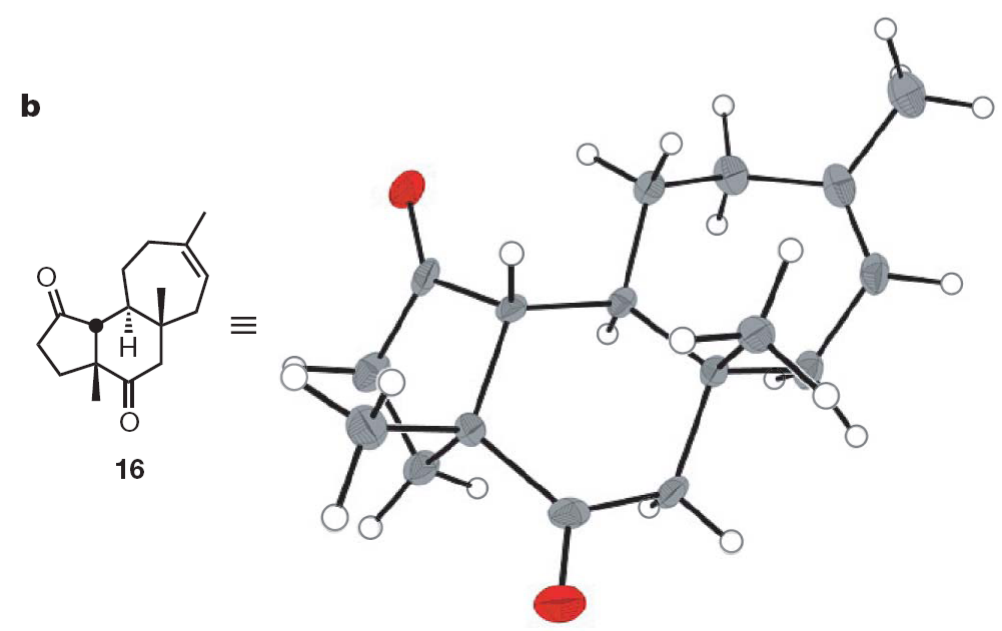

Figure 3. Synthesis of cyanthiwigin $F$

a, Completion of the cyanthiwigin F (1) synthesis. $6 \rightarrow \mathbf{4}:(1)$ KHMDS (1.1 equiv.), diketone 6 (1.0 equiv.), THF, $-78^{\circ} \mathrm{C}, 30 \mathrm{~min}$, then $\mathrm{PhN}(\mathrm{Tf})_{2}\left(1.2\right.$ equiv.), THF, $-78^{\circ} \mathrm{C}, 6 \mathrm{~h}, 84 \%$ yield; (2) $\mathrm{Zn}$ powder ( 7.5 equiv.), 1,2-dibromoethane (1.2 equiv.), TMSCl ( 0.33 equiv.), THF, $65^{\circ}$ $\mathrm{C}$ for $15 \mathrm{~min}$, then 4 -iodo-2-methyl-1-butene (1.5 equiv.), $65^{\circ} \mathrm{C}, 2 \mathrm{~h}$, then enol triflate $(1.0$ equiv.), $\mathrm{Pd}\left(\mathrm{PPh}_{3}\right)_{4}$ (0.05 equiv.), $65^{\circ} \mathrm{C}, 3 \mathrm{~h}, 78 \%$ yield. $\mathbf{4} \rightarrow \mathbf{1 5}$ : Tetraene 4 (1.0 equiv.), ruthenium catalyst 13 ( 0.1 equiv.), benzene, $40^{\circ} \mathrm{C}, 30 \mathrm{~min}$, then vinyl boronate 14 (5.0 equiv.), $40{ }^{\circ} \mathrm{C}, 20 \mathrm{~h}$, then $\mathrm{NaBO}_{3} \cdot \mathrm{H}_{2} \mathrm{O}$ (6.0 equiv.), THF/ $\mathrm{H}_{2} \mathrm{O}, 23{ }^{\circ} \mathrm{C}, 1 \mathrm{~h}, 51 \%$ yield. $15 \rightarrow \mathbf{1 6}$ : Bicyclic aldehyde 15 ( 1 equiv.), $t$-butyl thiol ( $t$-BuSH, 3.0 equiv.), $\operatorname{AIBN}\left(1.5\right.$ equiv.), benzene, $80{ }^{\circ} \mathrm{C}$, $22 \mathrm{~h}, 57 \%$ yield. 16 $\rightarrow \mathbf{1 :}$ (1) KHMDS (1.1 equiv.), diketone $\mathbf{1 6}$ ( 1 equiv.), THF, $-78{ }^{\circ} \mathrm{C}, 30$ min, then $\mathrm{PhN}(\mathrm{Tf})_{2}$ (1.15 equiv.), THF, $-78{ }^{\circ} \mathrm{C}, 3 \mathrm{~h}, 60 \%$ yield; (2) $\mathrm{CuCN}$ (1.5 equiv.), $i$ $\mathrm{PrMgCl}$ (3.0 equiv.), $\mathrm{THF},-78{ }^{\circ} \mathrm{C}$ to $0{ }^{\circ} \mathrm{C}$, then $0{ }^{\circ} \mathrm{C}$ for $10 \mathrm{~min}, \mathrm{Pd}(\mathrm{dppf}) \mathrm{Cl}_{2}$ ( 0.15 equiv.), enol triflate (1.0 equiv.), THF, $0{ }^{\circ} \mathrm{C}, 3 \mathrm{~h}, 63 \%$ yield of a 1.8:1 mixture of 1:17. b, Oak Ridge Thermal Ellipsoid Plot drawing of $\mathbf{1 6}$ (shown with 50\% probability ellipsoids). KHMDS, potassium bis(trimethylsilyl)amide; THF, tetrahydrofuran; $\mathrm{PhN}(\mathrm{Tf})_{2}$, phenyl bis 
(trifluoromethane)sulfonimide; TMSCl, trimethylsilyl chloride; AIBN, 2,2'-azobis (isobutyronitrile); dppf, 1,1'-bis(diphenylphosphino)ferrocene. For tabulated spectral data of all depicted compounds, and crystallographic data of tricyclic diketone 16, please see the Supplementary Information. 